\title{
DETECÇÃO MOLECULAR DE HEMOPLASMAS EM BOVINOS E OVINOS EM SISTEMA DE CRIAÇÃO CONSORCIADA DO NORDESTE DO BRASIL - DADOS PRELIMINARES
}

\author{
(Molecular characterization of hemoplasms in cattle and sheep from a consortiated breeding system in \\ northeast Brazil - Preliminary data)
}

Flávia C. M. Collere, Larissa D. R. Ferrari, lago C. Barbosa, Celso J. B. Oliveira, Thállitha S. W. J. Vieira, Rafael F. C. Vieira

\author{
Universidade Federal do Paraná, Curitiba, Paraná, Brasil.
}

*Correspondência: vieirarfc@gmail.com

RESUMO: Micoplasmas hemotrópicos (hemoplasmas) são microrganismos gram-negativos e que ficam aderidos aos eritrócitos de diversas espécies de mamíferos. Em pequenos ruminantes, Mycoplasma ovis, e em bovinos, Mycoplasma wenyonii e 'Candidatus Mycoplasma haemobos' são as espécies já descritas. Nessas espécies animais a transmissão dos hemoplasmas pode estar relacionada à infestação por carrapatos ou picadas de moscas hematófagas. A infecção por hemoplasmas pode causar anemia hemolítica aguda, porém os sinais clínicos diferem de acordo com a espécie de hemoplasma envolvido, do animal parasitado, idade e sistema de produção em que é criado. Embora a hemoplasmose tenha sido relatada causando perdas econômicas significativas na criação de ruminantes em todo o mundo, dados de hemoplasmas em sistema de criação consorciada são inexistentes. Assim, o objetivo deste estudo é determinar a prevalência de hemoplasmas em bovinos e pequenos ruminantes provenientes de um sistema de criação consorciada no nordeste do Brasil. As amostras de sangue foram previamente coletadas por punção venosa e armazenadas a $-80^{\circ} \mathrm{C}$. O DNA de cada amostra foi extraído de $200 \mathrm{uL}$ de sangue total utilizando-se um kit comercial (Qiagen Blood and Tissue ${ }^{\circledR}$ ), de acordo com as instruções do fabricante e quantificadas em aparelho de Nanodrop ${ }^{\circledR}$. Até o momento, um total de 15 amostras (10 ovinos e cinco bovinos) foram triadas utilizando um protocolo de PCR para o gene 16S rRNA de hemoplasmas, e as amostras positivas foram submetidas a PCR para detecção do gene 23S rRNA de hemoplasmas. Os produtos amplificados foram em seguida submetidos a eletroforese em gel de agarose a $1,5 \%$ por $50 \mathrm{~min}$ a $90 \mathrm{~V}$ e visualizado sob um trans iluminador de luz UV de $312 \mathrm{~nm}$. Todas as amostras foram positivas para o gene endógeno gliceraldeído 3-fosfato desidrogenase (gapdh). Todos as amostras de ovinos foram negativas para hemoplasmas, ou seja, não houve amplificação dos produtos da PCR. Três de cinco (60\%) bovinos foram positivos para Mycoplasma spp. Mesmo que todas as amostras de DNA ovino testadas para hemoplasmas tenham dado resultado negativo, não podemos descartar a presença deste hemoplasma nos demais animais do estudo. O estudo envolverá a triagem das amostras por PCR em tempo real.

Palavras-chave: diagnóstico molecular; Mycoplasma ovis, Mycoplasma wenyonii, 'Candidatus Mycoplasma haemobos'; PCR. 